K.A. Evers MD,

G.B. Eindhoven MD,

J.M.K.H. Wierda MD PhD

\title{
Transient nerve damage following intubation for trans-sphenoidal
hypophysectomy trans-sphenoidal
hypophysectomy
}

Purpose: To describe a case of transient lingual and hypoglossal nerve damage following intubation for a transsphenoidal hypophysectomy.

Clinical features: A 56-yr-old acromegalic man was scheduled for trans-sphenoidal hypophysectomy. He had been treated with octreotide six months previously which had reduced the swelling of the tongue to an acceptable degree to the patient. During the anesthetic procedure there were no problems. The intubation was performed without any difficulty, no force had been used to place the endotracheal tube, a throat pack was inserted and, before extubation, an oro-gastric tube was inserted. Three days after surgery the patient complained of numbness and swelling of the left side of the tongue, he had difficulty in moving the tongue, speaking difficulties and problems in swallowing food were noted. Also taste was lost on this side of the tongue. Left lingual and hypoglossal nerve damage was diagnosed, which was confirmed by the neurologist. After four months of intensive physiotherapy and speech therapy, the symptoms disappeared.

Conclusion: This is a report of a very rare complication of lingual and hypoglossal nerve damage in an acromegalic patient. This incident suggests forceful laryngoscopy, hyperextension of the head and the throat pack (tightly packed in the oropharynx) can result in injury of the lingual and the hypoglossal nerves.

Objectif : Décrire un cas d'atteinte transitoire des nerfs lingual et hypoglosse survenu lors d'une intubation pour une hypophysectomie trans-sphénoïdale.

Eléments cliniques : Un homme de 56 ans, atteint d'acromégalie, devait subir une hypophysectomie transsphénoïdale. II avait été traité avec de l'octréotide six mois auparavant, ce qui avait réduit l'hypertrophie de la langue à un degré acceptable pour lui. L'anesthésie s'est bien déroulée. L'intubation a été réalisée sans difficulté et aucune force n'a été appliquée pour mettre en place le tube endotrachéal. On a introduit une mèche au carrefour laryngo-pharyngé et, avant l'extubation, on a inséré un tube oro-gastrique. Trois jours après l'opération, le patient s'est plaint d'engourdissement et d'œedème du côté gauche de la langue. II éprouvait de la difficulté à bouger la langue, à parler et à avaler. II avait aussi perdu la sensibilité gustative de ce côté de la langue. On a diagnostiqué une atteinte des nerfs lingual et hypoglosse, ce que le neurologue a confirmé. Les symptômes ont disparus à la suite de quatre mois de séances intensives en physiothérapie et en orthophonie.

Conclusion : Nous avons présenté un cas d'atteinte des nerfs lingual et hypoglosse, complication très rare, chez un patient atteint d'acromégalie. Cet incident rappelle qu'une laryngoscopie ferme, l'hyperextension de la tête et l'introduction de la mèche (bien pressée dans l'oropharynx) peuvent entraîner un lésion des nerfs lingual et hypoglosse.

From the Department of Anesthesiology, University Hospital Groningen, P.O. Box 30.001, Hanzeplein 1, 9700RB, Groningen, the Netherlands.

Address correspondence to: Kim A. Evers MD. Phone: 32-50-3616161, Fax: 32-50-3613763, E-mail: K.A.Evers@anest.azg.nl Accepted for publication August 7, 1999 


\section{Case History}

A 56-yr-old, $85 \mathrm{~kg}$ male acromegalic patient was scheduled for a transsphenoidal hypophysectomy. $\mathrm{He}$ had a history of systemic hypertension which was treated with hydrochlorothiazide and verapamil. $\mathrm{He}$ had had signs of a carpal tunnel syndrome of his right arm but this had resolved after starting the treatment with octreotide. He had been treated with octreotide six months previously which had reduced the swelling of the tongue to an acceptable degree. On oral examination a huge tongue was noted and the airway was assessed as Mallampati class 1.8 One hour after premedication with $0.5 \mathrm{mg}$ atropine and $75 \mathrm{mg}$ meperidine $i m$, anesthesia was induced with $5 \mathrm{mg} \cdot \mathrm{kg}^{-1}$ thiopental, $0.5 \mathrm{mg} \cdot \mathrm{kg}^{.1}$ atracurium and $0.2 \mu \mathrm{g} \cdot \mathrm{kg}^{1}$ sufentanil $i v$, and was maintained with nitrous oxide $66 \%$ in oxygen and isoflurane $0.7 \%$ end tidal concentration and additional doses of sufentanil. The airway was maintained initially with an oral airway and facilitated by gently lifting the chin for three minutes of assisted ventilation after the administration of atracurium until intubation.

The trachea was intubated with an oral $9.0 \mathrm{~mm}$ preformed curved endotracheal tube. Both laryngoscopy and intubation were very easy. The cuff of the tube was inflated and attached to a pressure gauge in order to keep the cuff pressure $<20 \mathrm{~cm} \mathrm{H}_{2} \mathrm{O}$. The endotracheal tube was secured to the chin. A throat pack was placed in the pharynx. Surgery was carried out with the patient supine and lasted $180 \mathrm{~min}$. No laryngoscopy was used for placing the orogastric tube, it was inserted carefully and blindly after removal of the throat pack to drain gastric contents and blood.

Following extubation, the patient went to the recovery room. Three days after surgery, the patient complained of numbness and swelling of the left side of the

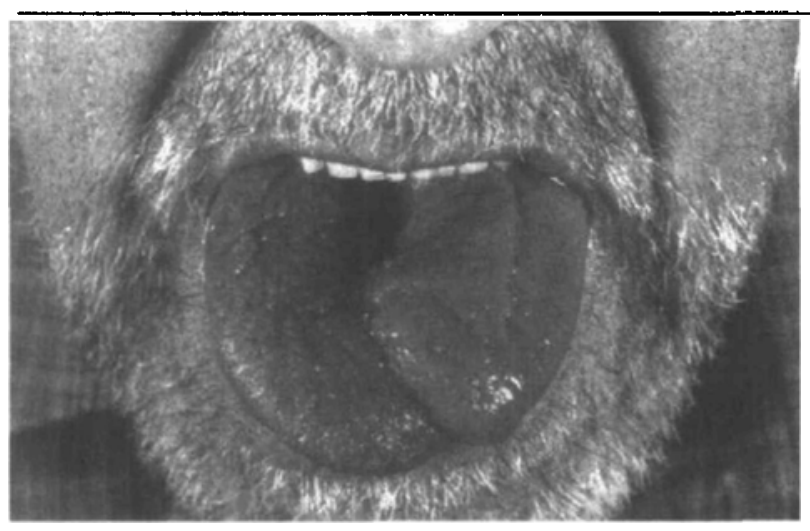

FIGURE Swelling of the left side of the tongue and on protrusion a slight deviation to the left. tongue; he had difficulty in moving his tongue resulting in speaking difficulties and problems in swallowing food. Also, he had loss of taste on the left side of the tongue. On direct questioning he admitted that the complaints had already been present on the first postoperative day.

External oral examination revealed no abnormal findings. In his mouth, swelling of the left side of the tongue was seen and on protrusion the tongue deviated slightly to the left.(Figure) A diagnosis of left lingual and hypoglossal nerve damage was made. The diagnosis was confirmed by a neurologist. His symptoms resolved gradually and had disappeared after four months; his speech improved with speech therapy.

\section{Discussion}

Lingual and hypoglossal nerve damage is a very rare complication of laryngoscopy and tracheal intubation. ${ }^{1-3}$ It has not been reported to date in acromegalic patients, although they are probably more vulnerable to such damage, considering their soft tissue overgrowth and bone enlargement. The more advanced the disease, the greater the risk of neurological complications. ${ }^{6}$

The lingual nerve is a branch of the posterior division of the mandibular nerve, arising in the infratemporal fossa. It enters the submandibular region by passing forwards and medially beneath the lower border of the superior constrictor muscle of the pharynx, where it is related medially to the styloglossus muscle and laterally to the lower third of the molar teeth. The nerve then passes forwards onto the lateral surface of the hyoglossus muscle. Sensory branches of the lingual nerve are distributed to the mucous membrane of the anterior two thirds of the tongue and the floor of the mouth and to the lingual surface of the gums. ${ }^{7}$

The hypoglossal nerve, on the other hand, is the motor nerve to the tongue muscles. It arises in the medulla oblongata and leaves the skull through the hypoglossal canal in the occipital bone. It then descends between the internal carotid artery and the internal jugular vein until it reaches the lower border of the posterior belly of the digastric muscle, where it turns forward and medially. ${ }^{7}$ Here, it lies below the deep part of the submandibular gland, the submandibular duct and the lingual nerve. At the anterior margin of the hypoglossus muscle it curves upwards towards the tip of the tongue, supplying branches of the tongue.

Acromegaly is the result of an excess of growth hormone. It is a disease which presents very late because of its insidious onset. It is associated with generalised bone and soft tissue thickening which results in the enlargement of many organs, including the hands, feet 
and tongue as well as laryngeal hypertrophy, sinus enlargement and prognathism. ${ }^{6}$

Prognathism and an enlarged tongue were prominent in our patient. Both can result in airway management problems; forceful mandibular retraction may be necessary to maintain the airway. ${ }^{4}$ When this is done, the lingual nerve can become compressed by the pterygoids. ${ }^{2}$ In our case no problems of this kind arose; a satisfactory airway was maintained by gently lifting the chin. Loughman points out that a difficult intubation where cricoid pressure or forceful laryngoscopy are employed can result in lingual and hypoglossal nerve injury. ${ }^{3}$

When cricoid pressure is applied or laryngeal displacement is used to facilitate visualisation of the larynx, the hyoid bone is immobilised while the tongue is displaced anteriorly; the lingual and hypoglossal nerves may be stretched as they cross the hyoglossus muscle. Direct compression of these nerves along their superficial course can also occur during forceful laryngoscopy and tracheal intubation. In our case, tracheal intubation was carried out without forceful laryngoscopy, cricoid pressure or laryngeal displacement.

Placing a throat pack can also result in direct compression of the lingual and hypoglossal nerves. The endotracheal tube has already been secured and laryngoscopy is often used to ensure its correct placement. This can exert pressure on the endotracheal tube while displacing the tube and the tongue anteriorly, so that the nerves are stretched. We used a laryngoscope while placing the throat pack. ${ }^{3}$ At this time, much less space than usual between the posterior region of the tongue and the endotracheal tube was noted. Since no compression of the tube at the tongue was seen when viewed directly, the endotracheal tube remained in the position in which it had been secured. Any increase in pressure on the base of the tongue, caused by insertion of the throat pack and the maneuvres involved in doing so, can cause compression of the lingual and hypoglossal nerves. Acromegalic patients may be more prone to this as a result of enlargement of the entire tongue and the greater susceptibility to neurological damage. ${ }^{6}$

\section{Conclusion}

Acromegalic patients are noted for occurrence of neurological complications owing to soft tissue thickening and bone enlargement e.g., carpal tunnel syndrome. ${ }^{5}$ Tissue overgrowth occurs in all organs, including the tongue and the larynx. Because of this enlargement a normal oral endotracheal tube may leave so little space at the base of the tongue in an adult patient, that a small degree of additional compression arising from a throat pack, hyperextension of the head or manipula- tion of the mouth can result in injury to the lingual and hypoglossal nerves.

Although this complication is very rare, it should be kept in mind and patients warned accordingly. We feel that intubation may be performed with the aid of a laryngoscope although we advise against the use of force during laryngoscopy. Furthermore the throat should be loosely packed, whereby prolonged pressure may be avoided.

\section{Acknowledgment}

We thank Dr. A.B. Buchthal, consultant anesthesiologist, for her help preparing this case report.

\section{References}

1 Silva $D A$, Colingo $K A$, Miller $R$. Lingual nerve injury following laryngoscopy. Anesthesiology 1992; 76: 650-1.

2 James FM III. Hypesthesia of the tongue. Anesthesiology 1975; 42: 359.

3 Loughman $E$. Lingual nerve injury following tracheal intubation. Anaesth Intensive Care 1986; 11: 171.

4 Majumder S, Hopkins PM. Bilateral lingual nerve injury following the use of the laryngeal mask airway. Anaesthesia 1998; 53: 184-6.

5 Mirenda J. Lingual nerve injury (Letter). Anesthesiology 1992; 77: 220-1.

6 Daniels GH, Martin JB. Neuroendocrine regulation and diseases of the anterior pituitary and hypothalamus. In: Wilson JD, Braunwald E (Eds.). Harrison's Principles of Internal Medicine, 12th ed. New York: McGraw-Hill, 1991: 1660-4.

7 Snell RS. Clinical Anatomy, 3rd ed. Boston/Toronto: Little, Brown, and Company, 1986: 780-1.

8 Benumof $J$. Management of the difficult adult airway. Anesthesiology 1991; 75: 1087-110. 